\title{
DETERMINASI POLITIK PADA PROSES \\ PEMBENTUKAN \\ DAN PENEGAKAN HUKUM DI INDONESIA
}

\author{
Abdul Rahman \\ Sekolah Tinggi Agama Islam Negeri (STAIN) Majene
}

\begin{abstract}
This article outlines the relationship between politics and law in the formation and enforcement of the law in Indonesia until the current reform era. There are three models of relations in describing legal and political relations. First, as Das Sein, the political determinant of the law because the law was born from the political process so that the law is a crystallization of competing for political desires. Secondly, as Das Sollen, the Law of determinants on the politics of every political agenda should be subject to the rules of the law. Thirdly, politics and laws influence each other because political lawlessness will be wronged while the law without an escort will be paralyzed. In the process of forming legislation by political institutions, the role of political power is very decisive because political institutions are formally given the authority in making the law. Political institutions that are not given such authority will become a vacuum. Here it appears that political institutions are only a tool of the group of political power holders. There are three main elements directly related to law enforcement efforts. First, the element of artificial law is a legislative institution. Second, the element of law enforcement is the police, prosecutors, and judges. Third, environmental elements that include personal citizens and social.
\end{abstract}

\section{Keywords:}

Determination, Politics, Law Formation, Enforcement

\begin{abstract}
Abstrak
Artikel ini menguraikan hubungan politik dan hukum dalam pembentukan dan penegakan hukum di Indonesia hingga era reformasi saat ini. Ada tiga model hubungan dalam menggambarkan hubungan hukum dan politik. Pertama, sebagai Das Sein, determinan politik hukum karena hukum lahir dari proses politik sehingga hukum merupakan kristalisasi persaingan keinginan politik. Kedua, sebagaimana Das Sollen, Hukum determinan politik dari setiap agenda politik harus tunduk pada aturan hukum. Ketiga, politik dan hukum saling mempengaruhi karena politik pelanggaran hukum akan dirugikan sedangkan hukum tanpa pengawalan akan lumpuh. Dalam
\end{abstract}


proses pembentukan peraturan perundang-undangan oleh lembaga politik, peran kekuasaan politik sangat menentukan karena lembaga politik secara formal diberi kewenangan untuk membuat undangundang. Lembaga politik yang tidak diberi kewenangan tersebut akan menjadi vakum. Di sini tampak bahwa lembaga politik hanyalah alat dari kelompok pemegang kekuasaan politik. Ada tiga unsur utama yang berkaitan langsung dengan upaya penegakan hukum. Pertama, unsur hukum buatan adalah lembaga legislatif. Kedua, unsur penegak hukum adalah polisi, jaksa, dan hakim. Ketiga, unsur lingkungan yang meliputi pribadi warga dan sosial.

\section{Kata Kunci:}

Determinasi, Politik, Pembentukan Hukum, Penegakan

\section{A. PENDAHULUAN}

\section{A}

da paradigma yang meyakini bahwa hukum adalah produk politik, karena kenyataannya wajah hukum sangat dipengaruhi oleh konfigurasi politik pada saat ia dibentuk (das sein). Namun paradigma yang lain justeru mengemukakan bahwa walaupun hukum dibuat dan lahir dari lembaga politik tetapi ketika hukum telah dinyatakan resmi berlaku maka politiklah yang harus tunduk kepada ketentuan hukum yang berlaku (das sollen). Kedua pandangan inilah yang menggelitik bagi penulis untuk menguraikan determinasi di antara keduanya.

Hingga era reformasi saat ini, kuatnya tekanan politik dalam proses pembentukan dan penegakan hukum masih terasa. Ini dikarenakan politik masih dijadikan sebagai panglima, yang memegang posisi kunci dalam menentukan model dan masa depan suatu negara. Bahkan, melalui kekuatan dan kebijakan politik, situasi tertentu dapat disetting sedemikian rupa berdasarkan kehendak yang sering didasarkan pada idealisme semu. Dari sinilah sehingga hukum sering disebut sebagai produk politik.

Secara empiris, adalah hal yang tidak bisa dipungakiri bahwa hukum lahir dari proses politik yang panjang. Namun sebagai negara hukum ${ }^{1}$, maka politiklah yang harus tunduk pada ketentuan-ketentuan hukum. Pandangan pertama didasarkan pada kenyataan bahwa karakter hukum sangat diwarnai oleh karakter politik yang melahirkannya.

Kritik umum terhadap karakter dan model penegakan hukum di Indonesia dilontarkan oleh kaum deterministik, dimana hukum diposisikan sebagai alat kekuasaan. Realitas tersebut manakalah dihubungkan dengan pelbagai pelanggaran dalam penyelenggaraan negara, maka hal itu bisa dipahami.

Selama pemerintahan dibawah kekuasaan orde baru, bahkan dalam banyak kasus pada era reformasi menunjukkan bahwa perangkat hukum telah "terkoyakkoyak" dan menjadi alat kepentingan politik. Hal ini menyebabkan menipisnya kepercayaan masyarakat terhadap hukum. Inilah tragedi panjang, yang sampai

\footnotetext{
${ }^{1}$ Pasal 1 ayat (3) UUD 1945.
} 
dewasa ini masih mewarnai pembentukan dan penegakan hukum di Indonesia².

Memang keberadaan hukum pada suatu negara, termasuk Indonesia sangat dipengaruhi secara dominatif oleh kekuatan politik terutama oleh kepentingan dari kelompok memegang kekuasaan, baik dalam pengambilan kebijakan maupun produk hukumnya. Imbasnya, seringkali hukum menjadi alat justifikasi terhadap suatu kebijakan, sehingga pembenaran terhadapnya pun harus diterima berdasarkan ketentuan yang tertuang dalam ketentuan hukum tersebut.

Untuk mewujudnyatakan Negara Kesatuan Republik Indonesia sebagai negara hukum, maka menjadi kewajiban bagi negara untuk melakukan pembangunan nasional secara terencana, terpadu dan berkelanjutan yang menjamin agar hak-hak setiap warga negara dapat terlindungi sesuai dengan ketentuan dalam UUD 1945, yaitu kehidupan yang adil dan makmur berdasarkan pancasila dan Undang-Undang Dasar 1945 yang bermuara kepada konsep negara kesejahteraan (welfare state) sebagai konsep negara modern. Oleh sebab itu, hukum harus diarahkan untuk mencapai tujuan hukum tersebut.

Hukum sebagai sarana untuk melihat suatu persoalan berdasarkan norma hukum yang salah satu sifatnya adalah memaksa. Hukum di satu sisi, seringkali harus melihat sesuatu itu secara "hitam putih" demi mewujudkan kepastian hukum, yakni menghukum yang bersalah dan membebaskan dari jeratan hukum bagi yang benar. Namun di sisi lain, kadangkala karena pertimbangan untuk mencapai keadilan ataupun kemanfaatan harus diarahkan kepada upaya pencapaian keadilan atau kemanfaatan, yang tidak harus melulu "hitam putih".

Secara empirik, politik adalah ranah yang sarat dengan "kepentingan" sehingga ia seringkali digunakan sebagai sarana untuk meraih kekuasaan, bagaimanapun caranya tanpa memperdulikan aspek legalitasnya jika cara tersebut dianggap sebagai jalan untuk dapat mewujudkan tujuannya.

Menariknya, pada tataran empirik antara politik dan hukum, yang notabene berbeda, ternyata justru saling mempengaruhi satu sama lain. Hukum sering mempengaruhi politik dan begitupun sebaliknya. Hukum merupakan produk dari pergulatan politik yang panjang. Proses pembentukan hukum tidak bisa terlepas dari tekanan dan kepentingan politik sebab ia lahir dari proses politik ${ }^{3}$, termasuk dalam penegakannya (law enforcement) yang tidak selalu bersih dari determinasi politik. Itulah sebabnya sehingga aturan hukum yang berlaku di Indonesia lebih seringkali bersifat represif daripada bersifat responsif dan akomodatif.

Untuk mengurai benang kusut hubungan keduanya, maka dapat dilihat dari gambaran sebagai berikut. Pertama, hukum determinan atas politik, dimana kegiatan-kegiatan politik diwarnai oleh ketentuan hukum. Kedua, politik determinan atas hukum, dimana hukum lahir dari pergulatan politik yang sarat dengan

\footnotetext{
${ }^{2}$ Satjipto Rahardjo, Masalah Penegakan Hukum (Jakarta: Sinar Ilmu, 1983)., h. 67

${ }^{3}$ http://www.republika.co.id/berita/breaking-news/nasional/09/02/26/33863-penegakan-hukum-masihdiintervensi-politik Selasa, 2 Muharram 1435 / 05 November 2013.
} 
kepentingan, dan hukum yang lahir merupakan cermina konfigurasi politi. ${ }^{4}$ Ketiga, argumentasi yang memandang bahwa keduanya saling mempengaruhi satu sama lain.

\section{B. INTERRELASI POLITIK DAN HUKUM}

Setiap orang seringkali memberikan kesimpulan yang berbeda mengenai hukum karena ia sangat kompleks yang menyangkut kenyataan kemasyarakatan yang plural dan mempunyai banyak fase, aspek dan dimensi.

Bernard Arif Sidarta mengemukakan bahwa hukum itu terbentuk dan berakar dari adanya interaksi pelbagai aspek kemasyarakatan seperti politik, sosial, ekonomi, budaya, teknologi, dan sebagainya. Ia dibentuk serta ikut membentuk struktuk kemasyarakatan sehingga modelnya mengikuti karakter masyarakat, dan juga ikut menjadi penentu sifat masyarakat dimana ia berlaku. ${ }^{5}$

Hukum sebagai produk politik, karakternya banyak dipengaruhi oleh pergulatan, model dan kekuatan politik yang melahirkannya. Disinalah hukum dapat dilihat sebagai cerminan pemikiran politik yang berinteraksi di kalangan para politisi.

Pada masa pemerintahan orde lama, Soekarno menjadikan politik sebagai panglima. Jargon itu lalu diganti menjadi "ekonomi dan pembangunan" pada era kekuasaan orde baru oleh Soeharto. Dengan alasan pembangunan (developmentalism), semua perbuatan negara selalu mengatasnamakan rakyat. Tapi ironisnya rakyat seringkali dijadikan sebagai obyek, hukum dijadikan sebagai alat justifikasi atas setiap tindakan dari penguasa. Akibatnya, segala bentuk peraturan yang dianggap tidak mampu mewujudkan stabilitas politik dan pertumbuhan ekonomi kemudian dihapus.

Jika dilihat dalam konteks situasi politik Indonesia dewasa ini, maka nampak bahwa politisasi lebih dominan daripada hukum. Sehingga produk hukum yang dihasilkan menjadi bukti telah terjadi kristalisasi tawar-menawar antar elite politik.

\section{DETERMINASI POLITIK DALAM PEMBENTUKAN HUKUM}

Dewasa ini, ilmuan hukum tidak lagi melihat hukum sebagai sebuah entitas yang independen terlepas dari politik, tetapi keduanya saling berhubungan dan saling melengkapi untuk mewujudkan pelbagai kepentingan dalam masyarakat. Hukum harus bisa berinteraksi dengan politik untuk menerjemahkan penyebab ketidaktaatan dan ketidakteraturan dalam masyarakat. Kebanyakan produk hukum sudah terpengaruh oleh kekuasaan yang disebabkan oleh kuatnya tekanan politik

\footnotetext{
${ }^{4}$ Moh. Mahfud MD, Perkembangan Politik: Studi Tentang Pengaruh Konfigurasi Politik Terhadap Produk Hukum Di Indonesia (Yogyakarta: Universitas Gadjah Mada, 1993)., 53.

${ }^{5}$ Imam Syaukani dan A. Ahsin Thohari, Dasar-Dasar Politik Hukum (Jakarta: RajaGrafindo Persada, 2010), h. 2.
} 
terhadap hukum. ${ }^{6}$

Kuatnya tekanan politik dalam proses legislasi sangat nampak dari produkproduk hukum yang ada. Hal ini sekaligus menjadi bukti nyata bahwa pada setiap tahapan pembentukan hukum (mulai dari perencanaan, penyusunan, pembahasan, pengesahan atau penetapan sampai pengundangan) tidak dapat terhindar dari adanya determinasi politik yang kuat.

Kuatnya tekanan politik tersebut juga mengakibatkan proses pembentukan perundang-undangan yang baik sesuai dengan dengan landasan dan asas pembentukan peraturan perundang-undangan menurut Pasal 7 UU. No. 12 tahun 2011 belum berjalan secara optimal. Sehingga berimplikasi terhadap masalah penegakan hukum kedepannya. Akibat yang lain adalah banyaknya gugatan uji materi (yudicial review) kepada mahkamah agung maupun mahkamah konstitusi terhadap beberapa peraturan perundang-undangan yang telah disahkan dan diundangkan.

Daniel S. Lev mengemukakan bahwa konsepsi dan struktur kekuasaan politik sangat menentukan dalam proses pembentukan dan penegakan hukum. Bahkan hukum sering dijadikan sebagai alat politik. Pembentukan dan penegakan hukum seringkali tergantung kepada stabilitas politik, kekuasaan, dan seterusnya. ${ }^{7}$

Dinamika pembentukan perundang-undangan dalam praktiknya sering terjadi seperti dimaksud di atas, walaupun tidak dimaksudkan demikian itu, disebabkan karena konsep dan susunan kekuasaan politiklah yang berlaku di tengah-tengah masyarakat dan cukup besar berpengaruhnya terhadap berlaku tidaknya suatu aturan hukum. Hal ini sebagai konsekuensi logis dari adanya ruang masuknya pengaruh politik dalam proses bembentukan hukum melalui isntitusi politik.

Kekuasaan politik adalah kemampuan mempengaruhi kebijakan umum, baik pada proses terbentuknya maupun akibat-akibatnya sesuai dengan pemegang kekuasaan ${ }^{8}$. Kekuatan politi dalam parlemen dan institusi politik lainnya sangat berperan dan menentukan pembentukan dan bahkan penegakan hukum. Institusi politik yang secara resmi mempunyai kewenangan membentuk hukum akan menjadi vacum jika tidak diberikan otoritas untuk itu.

Determinasi politik dapat dianalisas dari dua sisi. Pertama, sisi otoritas yang ada pada institusi politik (institusi negara) seperti presiden, Dewan Perwakilan Rakyat, maupun institusi-institusi lainnya. Kedua, sisi tekanan politik dari partai politik, organisasi-organisasi profesi, serta tokoh masyarakat.

Dari sini nampak dengan jelas bahwa produk-produk hukum itu banyak yang lahir dari determinasi kekuatan politik melalu proses politik dalam institusi-institusi

\footnotetext{
${ }^{6}$ Moh. Mahfud MD., Perkembangan Politik: Studi tentang Pengaruh Konfigurasi Politik terhadap Produk Hukum di Indonesia (Yogyakarta: Universitas Gadjah Mada, 1993), h. 26.

${ }^{7}$ Daniel S. Lev., Hukum Dan Politik di Indonesia, Kesinambungan dan Perubahan, Cet I (Jakarta: LP3S, 1990), h. xii.

${ }^{8}$ Miriam Budiardjo, Dasar-Dasar Ilmu Politik. Cet. ke 27 (Jakarta: PT Gramedia Pustaka Utama, 2005), h. 182.
} 
negara yang telah mendapatkan kewenangan untuk itu.

Terdapat tiga ladasan utama pada penyusunan perangkat hukum yaitu landasan yuridis, landasan sosiologis dan landasan filosofis ${ }^{9}$. Sedangkan Jimly Asshiddiqie mengemukakan lima landasan pembentukan hukum, yakni: ${ }^{10}$

1. Landasan filosofis, undang-undang harus mengandung norma-norma hukum yang diidealkan (ideal norm) oleh suatu masyarakat ke arah mana cita-cita luhur kehidupan bermasyarakat dan bernegara hendak diarahkan.

2. Landasan sosiologis, norma-norma hukum yang termaktub dalam aturan perundang-undangan haruslah sesuai dengan tuntutan kebutuhan riil masyarakat dan sesuai dengan realitas kesadaran hukum masyarakat.

3. Landasar politis, harus tercermin dalam konsiderans adanya sistem rujukan konstitusional sesuai dengan cita-cita dan norma dasar yang termuat dalam UUD 1945 sebagai sumber pokok kebijakan yang menjadi landasan pembentukan peraturan perundang-undangan yang bersangkutan.

4. Landasan yuridis, landasan ini harus diposisikan dalam konsiderans atau pengingat pada setiap perumusan perundang-undangan.

5. Landasan administratif, sifatnya sangat bergantung kepada kebutuhan, yang terdapat pada konsideran pada kata "memperhatikan". Landasan ini memerintahkan untuk mencantumkan dasar pijakan manakala ada perintah untuk melakukan pengaturan secara administratif.

Selain adanya determinasi dari institusi politik, juga ada pengaruh lain yang ikut memberikan kontribusi terhadap aturan perundang-undangan yang lahir dari lembaga-lembaga politik. Pengaruh dimaksud berasal dari kelompok kepentingan yang diakui serta dijamin eksistensi serta kewenangannya oleh konstitusi, sebagai konsekuensi logis dari sistem demokrasi yang dianut oleh negara, di antaranya adalah para ilmuan, pengusaha, organisasi profesi, organisasi kemasyarakatan, LSM, tokoh agama, termasuk mengakui adanya partisipasi masyarakat sebagaimana termaktub dalam UU. No. 10 tahun 2004 tentang Pembentukan Peraturan Perundang-Undangan, Bab X yang berbunyi: “ masyarakat berhak memberikan masukan secara lisan atau tulisan dalam rangka penyiapan atau pembahasan rancangan undang-undang dan rancangan peraturan daerah" ${ }^{11}$

Hasil dari perjuangan reformasi yang berbuah lahirnya pasal tersebut di atas telah nampak dengan ditolaknya banyak undang-undang yang dirasakan tidak mengakomodir aspirasi masyarakat, tidak mencerminkan rasa keadilan, serta memberikan kepastian hukum.

Menurut Daniel S. Lev bahwa timbulnya persoalan tersebut di atas disebabkan antara lain karena aturan perundang-undangan lahir dari sebuah proses yang tidak mengikuti landasan dan asas-asas pembentukan yang baik seperti telah disebutkan

\footnotetext{
${ }^{9}$ Bagir Manan, Dasar-Dasar Perundang-undangan di Indonesia (Jakarta: tp, 1992), h. 14.

${ }^{10}$ Jimly Asshiddiqie, Perihal Undang-Undang Di Indonesia (Jakreta: Sekretariat Jenderal dan Kepaniteraan Mahkamah Konstitusi RI MK, 2006), h. 170-174.

${ }^{11}$ Pasal 53 Bab X UU. No. 10 tahun 2004 tentang Pembentukan Peraturan Perundang-Undangan.
} 
pada ketentuan pembentukan aturan hukum menurut UU. Nomor 10 tahun 2004. Begitu pula dengan kajian naskah akademik yang dinilai tidak mendalam, mengabaikan kebutuhan dan aspirasi masyarakat dalam penyusunan prolegnas dan kurang mempertimbangkan harmonisasi serta sinkronisasi aturan perundangundangan. $^{12}$ Selain itu, timbulnya persoalan juga disebabkan oleh kurang profesionalnya sumber daya manusia yang merancang undang-undang, kurang membuka ruang partisipasi masyarakat untuk memberikan masukan secara lisan maupun tertulis.

\section{DETERMINASI POLITIK DALAM PENEGAKAN HUKUM}

Tidak dapat dipungkiri bahwa intervensi politik masih sangat kuat dalam Penegakan hukum di Indonesia, baik dalam proses-proses pembuatan kebijakan maupun pelaksanaannya di lembaga kepolisian, kejaksaan, serta peradilan. ${ }^{13}$ Ikrar Nusa Bakti mengemukakan bahwa walaupun Indonesia telah berhasil melewati fase di bawah kekuasaan pemerintahan otoriter orde baru, akan tetapi belum bisa lepas dari intervensi poiltik, sehingga acapkali tidak mencerminkan rasa keadilan hukum masyarakat. ${ }^{14}$

Todung Mulya Lubis mengemukakan bahwa kemandirian peradilan hanyalah slogas kosong dan mitos yang belum terwujud dalam kehidupan nyata. Ia mencontohkan proses pemilihan hakim agung, dimana calon yang merupakan hasil seleksi Komisi Yudisial lalu kemudian diserahkan kepada DPR RI. Di DPR lalu terjadi transaksi politik. Hasilnya adalah para calon hakim agung yang kemudian disodorkan ke Mahkamah Agung adalah buah dari kompromi politik. ${ }^{15}$ Betul ada yang namanya Hakim karir, akan tetapi mereka itu juga tidak steril dari adanya transaksi politik sebelumnya. Pada akhirnya kemandirian peradilan akan berdampak kepada institusi-institusi peradilan. Menurut Todung institusi-institusi tersebut harus ditata ulang agar bisa menjaga independensinya. Selain itu, melakukan reposisi DPR adalah sebuah keniscayaan. ${ }^{16}$

Akibatnya dari ketidakmandirian tersebut, sehingga produk-produk hukumnya banyak yang berbau hasil kompromi politik serta mengabaikan kepentingan masyarakat, sehingga banyak undang-undang yang dibuat oleh DPR yang kemudian diujikan ke Mahkamah Konstitusi untuk dimintakan uji materi (yudisial review). Wahyudi Jafar (Konsorsiaum Reformasi Hukum Nasional)

\footnotetext{
${ }^{12}$ Daniel S. Lev, Hukum Dan Politik di Indonesia, Kesinambungan dan Perubahan, Cet I. (Jakarta: LP3S, 1990), h. 69.

${ }^{13}$ Ikrar Nusa Bakti dari Lembaga Ilmu Pengetahuan Indonesia (LIPI) dan Todung Mulya Lubis, Ketua Dewan Pengurus Transparency International Indonesia, diungkapkan dalam Diskusi Intervensi Politik Terhadap Penegakan Hukum dan HAM di Kantor Komisi Yudisial, Jakarta.

${ }^{14}$ http://www.republika.co.id/berita/breaking-news/nasional/09/02/26/33863-penegakan-hukum-masihdiintervensi-politik Selasa, 2 Muharram 1435 / 05 November 2013.

${ }^{15}$ Todung Mulya Lubis, Ketua Dewan Pengurus Transparency International Indonesia, diungkapkan dalam Diskusi Intervensi Politik Terhadap Penegakan Hukum dan HAM di Kantor Komisi Yudisial, Jakarta.

${ }^{16}$ http://www.republika.co.id/berita/breaking-news/nasional/09/02/26/33863-penegakan-hukum-masihdiintervensi-politik Selasa, 2 Muharram 1435 / 05 November 2013.
} 
mengemukakan bahwa proses pembentukan undang-undang di DPR masih sarat dengan praktik transaksi politik. Oleh karena itu kemandirian peradilan harus menjadi program perioritas. ${ }^{17}$

Praktik diskriminasi dalam penegakan hukum, seperti dalam kasus-kasuk korupsi terutama yang dilakukan oleh anggota DPR serta kepala daerah banyak terjadi. Diskriminasi juga nampak dari banyaknya narapidana korupsi yang mendapatkan perlakuan khusus dalam penanganannya jika dibanding dengan pelaku kejahatan yang lain. Anggota DPRD yang telah dinyatakan terbukti bersalah berdasarkan keputusan pengadilan yang telah berkekuatan hukum (in krahct) menjadi bukti yang diskriminatif. Begitu pula dengan tidak diprosesnya secara adil para pelaku korupsi dana APBD. ${ }^{18}$

Menurut Soerjono Soekanto, terdapat lima faktor utama yang berpengaruh terhadap mekanisme penegakan hukum di Indonesia, yaitu:

1. Faktor substansi hukum (isi), dengan kata lain peraturan perundang-undangan yang isinya kurang tegas atau masih lemah mengatur mengenai sesuatu. Materi hukum juga seringkali tidak sinkron antara satu dengan lainnya, baik secara vertikal maupun horisontal.

2. Faktor aparat penegak hukumnya (struktur), yaitu para pihak yang terkait langsung baik dalam proses pembuatan hukum maupun pada penerapan/penegakan hukumnya. Misalnya aparat yang kurang bagus moralitas dan mentalitasnya, ataupun aparat yang kurang memahami substansi hukumnya, dan seterusnya.

3. Faktor sarana pendukung proses penegakan hukum. Katersediaan fasilitas sering tidak berbanding lurus dengan persoalan hukum yang menuntut penyelesaian.

4. Faktor masyarakat, yakni kebiasaan-kebiasaan masyarakat yang tidak mendukung penegakan hukum yang baik. Begitupun dengan lingkungan sosial dimana hukum itu diberlakukan atau diterapkan.

5. Faktor budaya, yaitu karya, rasa dan cipta yang bersumber dari karsa manusia dalam pergaulan hidupnya. ${ }^{19}$

Lain halnya dengan Satjipto Rahardjo, yang mengkategorikan pelbagai faktor yang memberikan kontribusi terhadap penegakan hukum menurut aspek kedekatannya dengan proses, yaitu kategori "agak jauh" dan "agak dekat". Menurut kategorisasi tersebut, ia membagi tiga unsur pokok yang terkait langsung upaya penegakan hukum, yaitu: (1) lembaga legislatif yang membuat undang-undang. (2) polisi, jaksa serta hakim sebagai unsur penegak hukum. (3) unsur lingkungan sosial

\footnotetext{
${ }^{17}$ Imam Syaukani dan A. Ahsin Thohari, Dasar-Dasar Politik Hukum (Jakarta: RajaGrafindo Persada, 2010), h. 10 .

${ }^{19}$ Soerjono Soekanto, Faktor-faktor Yang Mempengaruhi Penegakan Hukum (Jakarta: Rajawali, 1983), h.
} 
mencakup pribadi warga negara. ${ }^{20}$

Kedua-dua pendapat tersebut sesungguhnya tidak berbeda melainkan saling melengkapi. Lima faktor yang dikemukakan Soerjono Soekanto bisa dikemas ke dalam ketiga unsur seperti pandangan Satjipto Rahardjo. Begitupun sebaliknya bahwa ketiga unsur tersebut dapat pula dielaborasi ke dalam ke lima unsur sebagaimana menurut Sorjono Soekamto.

Ungkapkan yang mengatakan aturan perundang-undangan adalah lahir dari pergulatan dan merupakan produk politik, tidak dapat dipungkiri dalam artian bahwa undang-undang yang adalah merupakan buah kompromi dari pelbagai kekuatan sosial yang diiberlakukan serta ditegakkan untuk mewujudkan kepentingan serta tujuan dan untuk melindungi kepentingan individu, masyarakat, serta bangsa dan negara.

Aturan hukum merupakan refleksi atau wujud daripada kepentingankepentingan yang saling bersaingan dari konfigurasi politik yang melatarbelakanginya. ${ }^{21}$ Menurut Satjipto Rahardjo bahwa politik berkonsentrasi lebih besar antara sub-sistem hukum dengan sub-sistem politik yang menyebabkan hukum senantiasa berada pada posisi yang lemah. ${ }^{22}$ Karena itu, dalam menggambarkan determinasi politik dalam proses pembentukan dan penegakan hukum di Indonesia, Satjipto Raharjo mengatakan bahwa perjalanan perjalanan politik di Indonesia diibaratkan layaknya seperti kereta api yang berjalan di luar lintasan relnya. Pengandaian demikian itu disebabkan oleh banyaknya parktik politik yang secara substantif sangat bertentangan dengan aturan-aturan hukum yang berlaku.

Kondisi seperti ini menjadi bukti nyata bahwa politik sangat mempengaruhi bahkan menetukan bekerja atau tidaknya suatu aturan hukum, mulai dari proses pembentukan sampai kepada penerapannya di lapangan. Itulah sebabnya sehingga Mahfud MD mengatakan bahwa dalam hubungan timbal balik antara hukum dengan politik, terutama pada ranah hukum publik nampak terang benderang bahwa dalam sistem politik yang demokratis akan melahirkan suatu produk hukum yang berkarakter responsif dan populis. Sebaliknya, pada sistem politik yang otoriter akan melahirkan corak hukum yang ortodok dan konservatif.23

\section{E. KESIMPULAN}

Terdapat tiga model hubungan dalam menggambarkan hubungan hukum dan politik. Pertama, politik sangat menetukan corak dan karakter produk hukum karena kenyataannya hukum lahir dari sebuah proses politik dan merupakan cerminan dari

\footnotetext{
${ }^{20}$ Satjipto Rahardjo, Beberapa Pemikiran tentang Ancaman Antar Disiplin dalam Pembinaan Hukum Nasional (Bandung: Sinar Baru, 1985), h. 23-24.

${ }^{21}$ Moh. Mahfud MD, Politik Hukum (Yogyakarta: Universitas Gadjah Mada, 2011), h. 37.

${ }^{22}$ Satjipto Rahardjo, Beberapa Pemikiran tentang Ancaman Antar Disiplin dalam Pembinaan Hukum Nasional (Bandung: Sinar Baru, 1985), h. 71.

${ }^{23}$ Moh. Mahfud MD, Perkembangan Politik: Studi tentang Pengaruh Konfigurasi Politik terhadap Produk Hukum di Indonesia: Disertasi Doktor (Yogyakarta: Universitas Gadjah Mada, 1993), 56.
} 
keinginan-keinginan politik yang saling bersaing (das sein). Kedua, hukum mempengaruhi politik, dimana setiap agenda dan percaturan politik harus sesuai dengan ketentuan-ketentuan hukum yang berlaku (das sollen). Ketiga, politik mempengaruhi hukum dan sebaliknya hukum pun berpengaruh terhadap politik. Hukum tanpa pengawalan politik akan lumpuh, sedangkan politik tanpa hukum akan melahirkan kezaliman.

Peran kekuatan politik sangat berpengaruh dalam proses pembentukan produk hukum karena institusi politik secara yuridis mempunyai kewenangan untuk membentuk hukum. Institusi politik akan vakum jika tidak diberikan kekuasaan yang demikian itu. Disinilah nampak bahwa institusi politik hanyalah sebagai sarana dari kelompok-kelompok pemegang kekuasaan politik.

\section{Daftar Pustaka}

Asshiddiqie, Jimly. Perihal Undang-Undang Di Indonesia (Jakreta: Sekretariat Jenderal dan Kepaniteraan Mahkamah Konstitusi RI MK, 2006).

Budiardjo, Miriam. Dasar-Dasar Ilmu Politik. Cet. ke 27 (Jakarta: PT Gramedia Pustaka Utama, 2005)

http://www.republika.co.id/berita/breaking-news/nasional/09/02/26/33863-penegakanhukum-masih-diintervensi-politik Selasa, 2 Muharram 1435 / 05 November 2013.

Ikrar Nusa Bakti dari Lembaga Ilmu Pengetahuan Indonesia (LIPI) dan Todung Mulya Lubis, Ketua Dewan Pengurus Transparency International Indonesia, diungkapkan dalam Diskusi Intervensi Politik Terhadap Penegakan Hukum dan HAM di Kantor Komisi Yudisial, Jakarta.

Intervensi Politik Ancam Penegakan Hukum Pernyataan Pers Bersama Indonesia Corruption Watch dan Imparsial.

Lev, Daniel S. Hukum Dan Politik di Indonesia, Kesinambungan dan Perubahan, Cet I (Jakarta: LP3S, 1990).

Mahfud MD, Moh. Perkembangan Politik: Studi Tentang Pengaruh Konfigurasi Politik Terhadap Produk Hukum Di Indonesia (Yogyakarta: Universitas Gadjah Mada, 1993).

Mahfud MD, Moh. Politik Hukum (Yogyakarta: Universitas Gadjah Mada, 2011).

Manan, Bagir. Dasar-Dasar Perundang-undangan di Indonesia (Jakarta: tp, 1992).

Rahardjo, Satjipto. Beberapa Pemikiran tentang Ancaman Antar Disiplin dalam Pembinaan Hukum Nasional (Bandung: Sinar Baru, 1985).

Rahardjo, Satjipto. Masalah Penegakan Hukum (Jakarta: Sinar Ilmu, 1983). 
Soekanto, Soerjono. Faktor-faktor Yang Mempengaruhi Penegakan Hukum (Jakarta: Rajawali, 1983)

Syaukani, Imam dan Thohari, A. Ahsin. Dasar-Dasar Politik Hukum (Jakarta: RajaGrafindo Persada, 2010)

UU. No. 10 tahun 2004 tentang Pembentukan Peraturan Perundang-Undangan. 